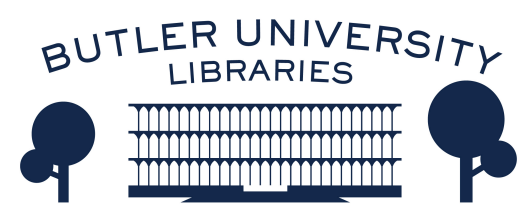

Journal of Hindu-Christian Studies

\title{
VIEWPOINT: Hinduism and the Academy: Towards a Dialogue Between Scholar and Practitioner
}

\author{
Ravi M. Gupta \\ Utah State University
}

Follow this and additional works at: https://digitalcommons.butler.edu/jhcs

Part of the Comparative Methodologies and Theories Commons, Hindu Studies Commons, and the Religious Thought, Theology and Philosophy of Religion Commons

\section{Recommended Citation}

Gupta, Ravi M. (2016) "VIEWPOINT: Hinduism and the Academy: Towards a Dialogue Between Scholar and Practitioner," Journal of Hindu-Christian Studies: Vol. 29, Article 9.

Available at: https://doi.org/10.7825/2164-6279.1632

The Journal of Hindu-Christian Studies is a publication of the Society for Hindu-Christian Studies. The digital version is made available by Digital Commons @ Butler University. For questions about the Journal or the Society, please contact cbauman@butler.edu. For more information about Digital Commons @ Butler University, please contact digitalscholarship@butler.edu. 


\title{
VIEWPOINT: Hinduism and the Academy: Towards a Dialogue Between Scholar and Practitioner
}

\author{
Ravi M. Gupta \\ Utah State University
}

IN an article for the Journal of the American Academy of Religion, Robert Segal proposes a model for thinking about the relationship between scholars and adherents of a religious tradition: the scholar, he says, is like the doctor and the adherent or practitioner is the patient. "Just as the patient has the disease but defers to the doctor's diagnosis, so the adherent has religion but defers, or should defer, to the scholar's analysis." (158). ${ }^{1}$ Although a practitioner of a religious tradition may have personal experience, argues Segal, we ought to turn to the scholar of religion in order to understand both the religion and the people who practice it.

Ebrahim Moosa responds vigorously to Segal in the same issue of JAAR. "To ask Segal's desperately ill patient to unwittingly surrender to the expert knowledge of a physician, despite the growing increase in cases of medical malpractice and physician error, is a risky business. . . . Any physician worth her salt cannot only rely on listening to the murmurs of the heart, the clarity of the lungs, or merely look at scans or the numeric indices of vascular pressures. The patient's history is critical to any treatment regime. Without knowledge from the patient about family history or even allergies, expertise in itself could be catastrophic." (173). ${ }^{2}$ One might raise other questions about the metaphor-should religion be seen as a disease to be cured? How would the metaphor work if we saw religion as a force for positive change? And what happens if the doctor and patient are the same person? Can a scholar practice the tradition he or she studies?

Recent decades have seen persistent tension between Hindus and scholars of Hinduism. There is, for example, ongoing disagreement over how Hinduism is taught in school textbooks, how scholars portray Hindu deities in their writing, and how we ought to conceive Hinduism's history. The accusations from both sides often become heated, with nationalist

Ravi M. Gupta is the Charles Redd Professor of Religious Studies and Director of the Religious Program at Utah State University. He is the author or editor of four books, including most recently (with Kenneth Valpey), The Bhagavata Purana: Selected Readings (Columbia University Press, 2016). He is a Permanent Research Fellow of the Oxford Centre for Hindu Studies and past president the Society for HinduChristian Studies. He has received three teaching awards, an NEH summer fellowship, and two research fellowships. Ravi lectures widely on topics related to Vaishnava bhakti traditions, Vedanta philosophy, and the Bhagavata Purana. He earned his doctorate at Oxford University and subsequently taught at the University of Florida, Centre College, and the College of William and Mary. 
politics, colonialist agendas, and missionary zeal allegedly part of the mix.

Clearly, both the practitioner's and the scholar's perspectives are useful-no, necessary-for understanding a religious tradition. Let us suppose, for a moment, that we are presented with a well-decorated cake. There are two ways of appreciating the gift we have received: one is to learn everything we can about the cake-who made it, what ingredients went into it, what theme was used to decorate it, how much it cost, how it was brought here, and so on. The other is simply to cut a slice and eat it. Both methods of understanding the cake are useful and necessary. Tasting the cake provides a direct experience that no amount of description or analysis can provide. At the same time, while experiencing the wonderful flavor, a person may become oblivious to questions of context and history. This requires some distance from the object itself, and academic study can provide that dispassionate distance.

The approaches of both the scholar and the practitioner bring essential capacities to the study of religion that cannot be replicated by the other, and those strengths can help make up for the weaknesses in the other's approach. Each side uses very different methods in order to achieve different goals. The practitioner seeks to explain his or her religion in a way that is comprehensive, consistent, and timeless. Take, for example, the much revered Hindu scriptures-the Upanișads. For many a Hindu, from the $8^{\text {th }}$ century Ādi Śamkara onward, the Upanișads offer a comprehensive and consistent revelation of ultimate reality. As Paul Griffiths so eloquently points out in Religious Reading, a religious person finds limitless meaning in a sacred text, like an inexhaustible well. Each reading produces new insights and fresh relevance, with no end to what one can gain (41). ${ }^{3}$ For a religious reader, the various elements of scripture come together in a seamless whole that is consistent across time, offering knowledge that is not otherwise available to human beings.

For a religious studies scholar, on the other hand, the scripture is a human product-and one that reflect all the frailties of the human mind, including inconsistent ideas and variations in the text as it was transmitted through the centuries. Academic study is marked by an overarching concern for historical and social context. The Upanișads, for instance, reflect the geographic rivalries between North Indian kingdoms in the sixth century BCE, and reveal changes in philosophical ideas from the early Upanișads to the later ones. We might draw another example from Catherine Bell, who describes her experience teaching Buddhism.

Whenever I present the history of Buddhist teachings and institutions, ... few want to hear about centuries of purely oral transmission, sectarian fracture and institutional fission, the late emergence of texts attributed to earlier figures, or rituals to advance one's material welfare in the here and now. It is not what we like to imagine for Buddhism, or for any religion. When we come across it, we can feel a bit disappointed. Discussion of these topics seems to deflate the possibility of the truth, or validity, or even the clear identity of Buddhist ideas. $(2)^{4}$

For the religious reader, the purpose of reading scripture is self-transformation and application in daily life; for the scholar, it is to understand the text's origins and its impact through history. The religious reader seeks 
Truth, the religious studies scholar sets aside the question of Truth, in favor of history and context.

Religious explanations offer an encompassing view of the world that puts everything in its proper place. From the sun and the moon to the creatures of the earth to social roles for human beings-all is explained in terms of their origin, proper function, and ultimate purpose. Comprehensive, consistent, and timeless-it is these three elements of the practitioner's approach that give religion its great power and capacity for changing the world. And no doubt, it is these elements that help give religion its extraordinary ability to provide meaning and purpose in the lives of adherents.

Nevertheless, the all-encompassing worldview can also engender problems, particularly in our globalized world. While the practitioner may find it useful to explain his neighbor's behavior in terms of his own religious framework, the neighbor may find the attempt to explain (and thus determine) her tradition to be threatening or even violent. Possessing a comprehensive worldview can lead to insular communities that justify oppression or avoid outsiders until war forces them into encounter.

It is here that scholarship can temper the absolutism of the practitioner's perspective with a healthy dose of history and context. One of the greatest gifts of academic study is its ability to contextualize religious behavior and beliefs. Historical circumstances-political exigencies, economics, social pressures, and the influx of foreign ideas can shape a religious tradition as powerfully as can divine revelation. A religious studies scholar might point out that when a tradition decides to retrieve something from the past, it is almost always innovating too. And so the scholar might remind us that adapting or renewing a tradition for changing times is as important as preserving the past, and that certain aspects of religious practice that are regarded as timeless may in fact be products of historical exigencies. The scholar's intellectual distance from the tradition can allow him or her to diagnose religious behavior when things go wrong-for example, when religion becomes the justification for oppression or the motivation for extremism-since a problem can often be seen more clearly and promptly from a distance than by some standing up close. The cure for the problem, however, often lies in the hands of the practitioner, for it is the practitioner who must mine the tradition and find the motivation for change from the inside.

And yet, despite its great usefulness, the scholar's approach can become its own worst enemy when taken too far. In trying to explain religion through the use of history, politics, or sociology, the scholar can explain it away, that is, devalue and deny a tradition's core values and claims, thus robbing the tradition of its beauty and power to effect change. The faithful perspective becomes seen as a myopic view of history that needs to be corrected and cured; the lay practitioner is regarded as naïve; and the religious leader becomes a perpetrator of that naïveté. In this situation, scholars claim a privileged position that is useful to no one but themselves, losing touch with the subject of study, or worse, making it the opponent. This dismissive stance of scholars toward religion can be seen with some regularity today, but it is perhaps most easily identified in scholarship of the past, which often provided the intellectual justification for colonization, conversion, or sanitization of these traditions. When scholarly 
devaluing takes place, the vociferous objections of practitioners-their attempts to revise a textbook, or raise objection at a conferenceserves as a useful reminder to scholars to practice their craft with care and balance.

It is no wonder, then, that faith and scholarship often find themselves at loggerheads. Each side is naturally suspicious of the other. For the practitioner, the academic approach is dry, tasteless, and boring. What does a man who has never tasted a piece of carrot cake know about carrot cake? What right does an outsider have to analyze someone else's faith? For a scholar, on the other hand, the practitioner's perspective is biased and lacking in context. It is something that should be analyzed, contextualized and perhaps deconstructed-it is the object of study-but it is not to be trusted on its own. What can a person who is busy licking the plate clean tell me about cake-making? Meanwhile, the scholarpractitioner, say, the Hindu who is a scholar of Hinduism, is the object of suspicion from both sides-from fellow scholars who fear that you might turn out to be an apologist for the tradition, and from your faith community, who fear that you might deconstruct their beliefs and practices.

And yet, despite the suspicions, the encounter between faith and scholarship is an unavoidable characteristic of the modern world, and as I have argued, necessary for a balanced discourse on religion. What we need is a dialogue of the two perspectives, a meeting of the practitioner and the scholar. Dispelling suspicions and initiating dialogue is a challenging task by any standard, but it must be done if we are to operate in a world where boundaries are increasingly fluid and the encounter between these perspectives is inevitable.

Dialogue, however, can take place only under carefully cultivated circumstances. Two people facing each other and talking is not necessarily a dialogue; it could very well be parallel monologues or merely a shouting match. What are the ingredients of a productive dialogue and how might one create that dialogue between scholars and practitioners? This is a major topic, and I offer only a few thoughts here.

First, we need to ask ourselves, "What are the rules of the dialogue, and who decides what the rules are?" Often, religious communities are reactive in their approach: when we feel that academic work has infringed upon the integrity and dignity of the tradition, we stand up and object. But why not be proactive and participate in the discussion ourselves? The questions we ask, the methods we use to answer them, the boundaries of the topic itself-all this is up for grabs. Participating in the process of definition is a much better way to enter the dialogue than to interject as an outsider once the rules of the game have already been established. Here, the role of the scholar-practitioner, the academically trained practitioner of a tradition, is crucial. Hindu students go on to become doctors, lawyers, engineers, scientists, and politicians. Isn't it time that more choose to formally study their own traditions?

Making this crucial choice will not only create a genuine dialogue between Hinduism and academia, it will also change the nature of that dialogue by breaking down easy categories-insider and outsider, scholar and practitioner, Indian and Western. For genuine dialogue to take place, each side has to be willing to give up preset boundaries and easy 
categories. "Scholarship and faith are inherently opposed to each other." "Being a Hindu means believing these ten things." "They are the bullies and we are the victims."

I have found that one of the most important ingredients of effective dialogue between scholars and practitioners is methodological humility. I call it "methodological" because my concern here is not whether someone considers themselves a humble person or whether they think that humility is a good thing. Rather, I am concerned with the fact that effective dialogue requires a humility of method-a recognition of the limitations of one's perspective and a willingness to learn from the other. More specifically, for practitioners of the tradition, humility means that we are willing to take the time to understand the principles underlying

\section{Notes}

${ }^{1}$ Segal, Robert A. "All Generalizations are Bad: Postmodernism on Theories." Journal of the American Academy of Religion. 74.1 (2006) 157-171.

${ }^{2}$ Moosa, Ebrahim, "Response to Robert Segal." Journal of the American Academy of Religion. 74.1 (2006) 172-175.

${ }^{3}$ Griffiths, Paul J. Religious Reading: The Place of Reading in the Practice of Religion. New York: Oxford University Press, 1999. academic work, that we take the trouble to become trained in its methods, and that we are willing to listen and engage even when the topic becomes uncomfortable. For academics, humility means that when the evidence could go either way, we are willing to give the benefit of doubt to the tradition; that we are willing to see our work through the eyes of tradition; that we write in a way that those whom we study can recognize themselves in our work; and that we always hold ourselves accountable, not just to our peers, but to the communities that we study. When such humility is reflected on both sides, dialogue can flourish. When both scholars and practitioners bring their strengths to the dialogue table, question easy categorization, and acknowledge their own weaknesses, we just might be able to study our cake and eat it too.

\footnotetext{
${ }^{4}$ Bell, Catherine M. Who Owns Tradition? Religion and the Messiness of History. The Santa Clara Lectures, vol. 7, no. 2. Santa Clara, CA: Santa Clara University, Bannen Institute for Jesuit Education and Christian Values, 2001. http://www.scu.edu/ic/publications/ upload/scl-0102-bell.pdf.
} 